\title{
Genetics of rotator cuff tears: no association of col5a1 gene in a case-control study
}

\author{
Umile Giuseppe Longo ${ }^{1,5^{*}}$ D, Katia Margiotti ${ }^{2,3}$, Stefano Petrillo ${ }^{1}$, Giacomo Rizzello ${ }^{1}$, Caterina Fusilli ${ }^{4}$,
} Nicola Maffulli5, ${ }^{5,6}$, Alessandro De Luca ${ }^{2}$ and Vincenzo Denaro ${ }^{1}$

\begin{abstract}
Background: The incidence of RC tears increases with aging, affecting approximately 30 to 50\% of individuals older than 50 years, and more than $50 \%$ of individuals older than 80 years. Intrinsic factors (age or gender), extrinsic factors (sports activity or occupation), and biological factors were identified in the onset and progression of RC tears. The attention in the study of aetiology of RC tendinopathy has shifted to the identification of gene variants. Genes encoding for proteins regulating the concentration of pyrophosphate in the extracellular matrix and genes encoding for fibroblastic growth factors, defensin beta 1 and estrogen-related receptor-beta were analyzed. However, only in one study the role of variants of collagen type $V$ alpha 1 (col5a1) gene in RC tears was assessed. The objective of this study was to determine whether a col5a1 DNA sequence variant, rs12722 (C/T) was associated with rotator cuff (RC) tears in a case-control study.

Methods: The study included 93 Caucasian patients undergoing surgery for RC tears and 206 patients with no history and sign of RC disease as evaluated by MRI. Patients were divided into two groups. Group 1 included patients with RC tear diagnosed on clinical and imaging grounds and confirmed at the time of surgery. Group 2 (control group) included patients without history or clinical symptoms of RC disorders and with a MRI negative for RC disease. DNA was obtained from approximately $1.2 \mathrm{ml}$ of venous blood using the MagCore extractor system H16 with a MagCore Genomic DNA Large Volume Whole Blood Kit (RBC Bioscience Corp., Taiwan). All study participants were genotyped for SNPs rs12722.
\end{abstract}

Results: We first estimated that our study had $92 \%$ power at $p<0.05$ to detect a genetic effect size of 2.05 in the RT tears (93 individuals) and healthy population (206 individuals) cohorts, assuming a minor allele frequency for col5a1 variant rs 12722 of 0.5707 in the Italian population (gnomAD frequency). No significant difference in allele and genotype frequencies was observed between RT tears patients and healthy controls. Similarly, no significant association was seen between the RT tears and healthy controls participants in the combined genotype distributions.

Conclusion: In conclusion, no correlations between the SNP rs12722 of col5a1 gene and RC tears susceptibility was found.

Keywords: Genetics, Rotator cuff, Tears, Shoulder, Arthroscopy, Gene

\footnotetext{
* Correspondence: g.longo@unicampus.it

${ }^{1}$ Department of Orthopaedics and Trauma Surgery, Campus Bio-Medico

University of Rome, Rome, Italy

${ }^{5}$ Department of Orthopaedics and Traumatology, Azienda Ospedaliera San

Giovanni di Dio e Ruggi d'Aragona, University of Salerno, Salerno, Italy

Full list of author information is available at the end of the article
}

(c) The Author(s). 2018 Open Access This article is distributed under the terms of the Creative Commons Attribution 4.0 International License (http://creativecommons.org/licenses/by/4.0/), which permits unrestricted use, distribution, and reproduction in any medium, provided you give appropriate credit to the original author(s) and the source, provide a link to the Creative Commons license, and indicate if changes were made. The Creative Commons Public Domain Dedication waiver (http://creativecommons.org/publicdomain/zero/1.0/) applies to the data made available in this article, unless otherwise stated. 


\section{Background}

Rotator cuff (RC) pathologies represent the costliest problem in Workers' Compensation Systems after low-back pain, with a prevalence rate ranging from 5 to $39 \%$ in the general population [1]. The incidence of $\mathrm{RC}$ tears increases with aging, affecting approximately 30 to $50 \%$ of individuals older than 50 years, and more than $50 \%$ of individuals older than 80 years [2].

Although several innovations and valuable surgical techniques were developed in the field of RC treatment, the understanding of aetiology of RC tears and related pathogenesis is still unclear. Intrinsic factors (age or gender), extrinsic factors (sports activity or occupation), and biological factors were identified in the onset and progression of RC tears [1].

However, in the last decade, the attention in the study of aetiology of RC tendinopathy has shifted to the identification of gene variants. Harvie et al. [3] was the first suggesting the genetic susceptibility towards the development of $\mathrm{RC}$ tears, demonstrating that siblings had a significantly increased risk of developing RC tears. Furthermore, they demonstrated that $\mathrm{RC}$ tears in siblings are more likely to progress over a period of 5 years [4]. Peach et al. [5] found that $\mathrm{RC}$ tears were associated with variants of genes (ANHK and TNAP) encoding for proteins regulating the concentration of pyrophosphate in the extracellular matrix (ECM). ANKH is the human homologue of the mouse progressive ankylosis gene (ank) and encodes a multipass transmembrane protein transporting $\mathrm{PPi}$ from inside chondrocytes. TNAP encodes the protein TissueNonspecific Alkaline Phosphatase which hydrolyses PPi to $\mathrm{Pi}$ and an increase or decrease in concentrations of the enzyme will decrease or increase PPi concentration levels respectively [5]. Moreover, 15 single nucleotide peptide polymorphism (SNPs) were detected in patients with RC tears in the Tenascin-C (TNC) gene [6], and TNC protein is expressed upon tissue damage and has an important role in ECM synthesis and organization in injured tendon tissue. Motta et al. [7] showed a correlation between RC tears and variants of SNPs in genes encoding for fibroblastic growth factors (FGFs) and defensin beta 1 (DEFB1), which are both immune modulating proteins. Furthermore, variants of genes encoding for estrogen-related receptor-beta (ESRRB), which is a crucial protein for the response of tissues to hypoxia, were associated with an increased prevalence of $\mathrm{RC}$ tears.

col5a1 gene encodes for the alpha 1 chain of type $\mathrm{V}$ collagen (OMIM 120215), which is a major constituent of bundles in tendons and ligaments [8]. This protein is fundamental in the regulation of the diameter of type I collagen fibrils, and different SNPs of col5a1 gene were associated with Achilles and elbow tendinopathies $[9,10]$.

However, only in one study the role of variants of collagen type $\mathrm{V}$ alpha 1 (col5a1) gene in $\mathrm{RC}$ tears was assessed without any significant result [6]. In this study, in fact, differences in genotype and allele frequencies between patient and control groups did not differ significantly for SNPs in MMP-1, MMP-2, MMP-3, MMP-9, MMP-13, and Col5a1 genes [6].

The objective of this study was to determine whether a col5a1 DNA sequence variant, $\operatorname{rs} 12722(\mathrm{C} / \mathrm{T})$ was associated with RC tears in a case-control study.

\section{Methods}

The present study was approved by the local Ethics committee of Campus Bio Medico of Rome. All participants were recruited at the University Hospital Campus Bio-Medico of Rome.

\section{Study population}

All patients are divided into two groups: the first was the study group and the second was the control group. Patients in Group 1 were included in the study if they had $\mathrm{RC}$ tear diagnosed on clinical and imaging grounds and confirmed at the time of surgery. Conservative management, including nonsteroidal anti-inflammatory drugs, physiotherapy, and rest, failed in all patients, and they continued to experience unacceptable pain and weakness in the affected shoulder. None of the patients had undergone prior surgery on the affected shoulder. All patients fulfilled the following criteria: (1) positive rotator cuff lag signs on preoperative examination (at least one among Jobe test, Napoleon test, lift-off test, and Patte test), (2) no episodes of shoulder instability, (3) no radiographic sign of fracture of the glenoid or the tuberosities, (4) magnetic resonance imaging (MRI) evidence of cuff tear, (5) RC tear of 1 or more tendons at arthroscopic examination, and (6) no lesion of the glenoid labrum or of the capsule at arthroscopic examination. Patients in Group 2 were included in the study if they had no history or signs of RC tears and if they had an intact RC at MRI.

Patients were excluded in case of primary osteoarthritis of the operated or contralateral shoulder, inflammatory joint disease. Patients in Group 2 were also excluded from the study if they have had history of shoulder pain or rotator cuff pathology diagnosed by imaging or on clinical grounds.

\section{Genetic analysis \\ DNA extraction}

DNA was obtained from approximately $1.2 \mathrm{ml}$ of venous blood using the MagCore extractor system H16 with a MagCore Genomic DNA Large Volume Whole Blood Kit (RBC Bioscience Corp., Taiwan).

\section{Genotyping}

All study participants were genotyped for SNPs rs12722 by means of ready-to-use TaqMan assay on an HT 7900 
platform (Life Technologies, Carlsbad, California, United States of America). The PCR primers and TaqMan probes were designed by Primer Express and optimized according to the manufacturer's protocol. Genotyping quality was tested by including twelve blinded duplicate samples (four duplicate for each rs12722 SNP genotype: TT, CT, CC) in each 384-well assay. The average agreement rate of duplicate samples was $>99$.

\section{Statistical analysis}

Quanto V.1.2.4 was used to determine the statistical power for a given sample size and minor allele frequency [11]. Hardy-Weinberg equilibrium (HWE) for rs12722 SNP in patients and controls was computed through Hardy Weinberg software (HardyWeinberg R-3.3.2 version 1.5.8; http://www.jstatsoft.org). A stats $\mathrm{R}$ for windows ( $\mathrm{R}$ stat software package 3.3.2; https://www.r-project.org) was used to compute Odds Ratios and their associated 95\% confidence intervals, and $p$-values for the genotypes of rs12722 $(\mathrm{C} / \mathrm{T})$. Logistic regression was used for recessive and dominant models.

\section{Results}

The study included 93 Caucasian patients undergoing surgery for RC tears and 206 patients with no history and sign of RC disease as evaluated by magnetic resonance imaging (MRI). Group 1 (study group) included 93 patients with RC tears. 40 (43\%) were males and 53 (57\%) females, with a mean age of $56.9+9.4$ (range 40 to 76 years). The dominant arm was affected in 62 (66.6\%) patients. Group 2 (control group) included 206 patients without history or clinical symptoms of RC disorders and with a MRI negative for RC disease. This group included 94 males (45\%) and 112 (55\%) females; mean age: $58.7 \pm 8.3$ (range 41 to 75 years).

We first estimated that our study had $92 \%$ power at $p$ $<0.05$ to detect a genetic effect size of 2.05 in the RT tears (93 individuals) and healthy population (206 individuals) cohorts, assuming a minor allele frequency for col5a1 variant rs12722 of 0.5707 in the Italian population (gnomAD frequency). Genotype data for the rs12722 variant in both study and control groups was tested and found to be in HWE (Table 1). No significant difference in allele and genotype frequencies was observed between RT tears patients and healthy controls (Table 1). Similarly, no significant association was seen between the RT tears and healthy controls participants in the combined genotype distributions (Table 2).

\section{Discussion}

The main findings of this study is that there is no correlations between the SNP rs12722 of col5a1 gene and RC tears susceptibility.

s12722 is a common $\mathrm{C}$ to $\mathrm{T}$ single nucleotide polymorphism (SNP) located in the functional 3' untranslated region ( $3^{\prime}$ UTR) col5a1 gene on chromosome 9 at position 134,842,570 [12]. This SNP is considered to be a novel genetic marker for endurance running performance [13] and is also associated with the development of bilateral quadriceps tendon rupture and with chronic Achilles tendinopathy [14].

Following the results reported by Mokone et al. [9] and Altinisik et al. [10] on the correlation between SNPs of colsa1 gene and Achilles tendinopathy or chronic degenerative tendon changes at the elbow respectively, there has been an increased interest on the potential association of this polymorphism and the risk of developing a $\mathrm{RC}$ tear. These results are similar to those reported by Kluger et al. [6] in two different cohorts of patients (1st: 59 patients with RC tears and 32 controls; 2nd: 96 patients with $\mathrm{RC}$ tears and 44 controls). However, the authors found 6 SNPs of TNC gene associated with degenerative $\mathrm{RC}$ tears, but the most important limitation of their study was that the diagnosis of RC tears was made with ultrasounds, which is an investigator-specific technique with lower sensitivity compared to the techniques (magnetic resonance and arthroscopy) used in the present study [6].

The understanding of the aetiology and pathogenesis of RC tears is still unclear and both intrinsic and extrinsic factors have been advocated [15-26].

In the last decade, a huge number of researchers have focused their attention on the study of genetic susceptibility of RC tears. Peach et al. [5] showed a significant correlation between variants of $A N H K$ and TNAP genes and RC tears, while Motta et al. [7] found that haplotypes CCTTCCAG in ESRRB, CGACG in FGF3, CC in DEFB1, FGFR1 rs13317, FGF10 rs11750845 and rs1011814 were associated with RC tears. Tashjian et al. [27] confirmed the results of Motta et al. [7] on the role of ESRRB in RC tears, showing also that genetic variants of ESRRB gene was associated with failure of RC healing,

Table 1 HWE assessment and case-control association analysis of COL5A1 rs12722 variant by allele and genotype

\begin{tabular}{|c|c|c|c|c|c|c|}
\hline & \multicolumn{3}{|c|}{ Genotypic frequencies (\%) } & \multicolumn{2}{|c|}{ Allelic frequencies (\%) } & \multirow{2}{*}{$\begin{array}{l}\text { HWE } \\
p \text {-value }\end{array}$} \\
\hline & $T / T$ & $C / T$ & $\mathrm{C} / \mathrm{C}$ & $\mathrm{T}$ & $C$ & \\
\hline $\mathrm{RC}$ tears patients $(N=93)$ & $33(35.5)$ & $46(49.5)$ & $14(15.1)$ & $112(60.22 \%)$ & $74(39.78 \%)$ & 0.8311 \\
\hline Healthy controls $(N=206)$ & $74(35.9 \%)$ & $101(49 \%)$ & $31(15.0 \%)$ & 249 (60.44\%) & 163 (39.56\%) & 0.7720 \\
\hline
\end{tabular}

Genotype and allele frequencies are expressed as percentages with numbers $(\mathrm{N})$ in parenthesis. HWE Hardy-Weinberg equilibrium 
Table 2 Case-control association analysis of COL5A1 rs12722 variant by combined genotype distributions

\begin{tabular}{lll}
\hline Genotype comparisons & OR (Cl 95\%) & $p$-value \\
\hline$\Pi+$ CT vs CC & $1.0004(0.504-1.984)$ & 0,9991 \\
$\pi$ T vs CT + CC & $1.0193(0.611-1.70)$ & 0,9416 \\
$\Pi T$ vs CT & $1.0213(0.596-1.750)$ & 0,9388 \\
$\Pi$ T vs CC & $1.0127(0.477-2.150)$ & 0,9738 \\
\hline
\end{tabular}

$O R$ odds ratio, $\mathrm{Cl}$ confidence interval

and that positive family history of $\mathrm{RC}$ tear increases the risk for healing failure [28, 29].

Our interest in SNP rs12722 of col5a1 gene raised from the significant correlation between such SNP and Achilles tendon tears or tendinopathy [9]. Mokone et al. [9] enrolled 111 Caucasian patients with Achilles tendon pathology and 129 healthy controls. All patients were genotyped for the BstUI (marker rs12722) and DpnII (marker rs13946) restriction fragment length polymorphisms (RFLPs) within the col5a1 gene, detecting significant difference in the allele frequencies of the colsa1 BstUI RFLP between the two groups. They concluded that col5a1 BstUI RFLP were associated with chronic Achilles tendinopathy [9].

The main strengths of our study are that we have enrolled only Caucasian patients in both study group and control group. Another strength is that the study group included patients who had both MRI and arthroscopic diagnosis of RC tears, while the control group was composed by healthy individuals without history or symptoms of RC disorders who underwent a MRI to confirm that the $\mathrm{RC}$ was intact. Furthermore, to improve the quality of the genetic analysis, we have included only Caucasian individuals with Italian origins.

Nevertheless, we are aware of the important limitation of our study. We have tested only the SNP rs12722 of col5a1 gene and it is possible to hypothesize that genetic variations at this gene could still be present in other SNPs areas and may be related with RC tears. Moreover, we have not collected other parameters such as comorbidities that could be involved as risk factors for the development of RCT. This could be the subject of future endeavours.

\section{Conclusion}

In conclusion, no correlations between the SNP rs12722 of col5a1 gene and RC tears susceptibility was found.

\section{Abbreviations}

ANHK: human homolog (ANKH) of the mouse progressive ankylosis (ank) gene; DEFB1: defensin beta 1; ESRRB: estrogen-related receptor-beta; FGF: fibroblastic growth factor; HWE: Hardy-Weinberg equilibrium; MRI: magnetic resonance imaging; RC: rotator cuff; RFLP: restriction fragment length polymorphism; ROS: reactive oxygen species; SNP: single nucleotide peptide polymorphism; TNAP: Tissue-nonspecific alkaline phosphatase; TNC: Tenascin-C gene

\section{Acknowledgements}

Not applicable.

\section{Funding}

Not applicable.

Availability of data and materials

The datasets used and/or analysed during the current study available from the corresponding author on reasonable request.

\section{Authors' contributions}

All authors have read and approved the manuscript. UGL: manuscript preparation, study design, database interpretation and manuscript revision. KM and SP: manuscript preparation, database interpretation and statistical analysis. GR, CF and ADL: manuscript preparation, figures and tables preparation, study design. NM: Manuscript preparation and database interpretation. VD: Study design, manuscript revision.

\section{Ethics approval and consent to participate}

The ethics committee of the university "Campus Bio Medico" of Rome approved the study and all patients gave written consent to participate.

\section{Consent for publication}

Written informed consent to publish this information was obtained from study participants. All the data are available for the consultation.

\section{Competing interests}

UGL is a member of the Editorial Board of BMC Musculoskeletal Disorders. The remaining authors declare that they have no conflict of interest.

\section{Publisher's Note}

Springer Nature remains neutral with regard to jurisdictional claims in published maps and institutional affiliations.

\section{Author details}

'Department of Orthopaedics and Trauma Surgery, Campus Bio-Medico University of Rome, Rome, Italy. ${ }^{2}$ Molecular Genetics Unit, Casa Sollievo della Sofferenza Hospital, IRCCS, San Giovanni Rotondo, Italy. ${ }^{3}$ ALTAMEDICA, Laboratorio Genetica Medica, Roma, Italy. ${ }^{4}$ Bioinformatics Unit, Casa Sollievo della Sofferenza Hospital, IRCCS, San Giovanni Rotondo, Italy. ${ }^{5}$ Department of Orthopaedics and Traumatology, Azienda Ospedaliera San Giovanni di Dio e Ruggi d'Aragona, University of Salerno, Salerno, Italy. ${ }^{6}$ Queen Mary University of London, Barts and the London School of Medicine and Dentistry, Centre for Sports and Exercise Medicine, Centre for Sports and Exercise Medicine, Mile End Hospital, London, UK.

Received: 8 September 2018 Accepted: 27 November 2018

Published online: 20 December 2018

\section{References}

1. Longo UG, Berton A, Papapietro N, Maffulli N, Denaro V. Epidemiology, genetics and biological factors of rotator cuff tears. Med Sport Sci. 2012;57:1-9.

2. Longo UG, Salvatore G, Rizzello G, Berton A, Ciuffreda M, Candela V, Denaro $V$. The burden of rotator cuff surgery in Italy: a nationwide registry study. Arch Orthop Trauma Surg. 2017;137:217-24.

3. Harvie P, Ostlere SJ, Teh J, McNally EG, Clipsham K, Burston BJ, Pollard TC, Carr AJ. Genetic influences in the aetiology of tears of the rotator cuff. Sibling risk of a full-thickness tear. J Bone Joint Surg Br. 2004;86:696-700.

4. Gwilym SE, Watkins B, Cooper CD, Harvie P, Auplish S, Pollard TC, Rees JL, Carr AJ. Genetic influences in the progression of tears of the rotator cuff. J Bone Joint Surg Br. 2009;91:915-7.

5. Peach CA, Zhang Y, Dunford JE, Brown MA, Carr AJ. Cuff tear arthropathy: evidence of functional variation in pyrophosphate metabolism genes. Clin Orthop Relat Res. 2007:462:67-72.

6. Kluger R, Burgstaller J, Vogl C, Brem G, Skultety M, Mueller S. Candidate gene approach identifies six SNPs in tenascin-C (TNC) associated with degenerative rotator cuff tears. J Orthop Res. 2017;35:894-901.

7. Motta GR, Amaral MV, Rezende E, Pitta R, Vieira TC, Duarte ME, Vieira AR, Casado PL. Evidence of genetic variations associated with rotator cuff disease. J Shoulder Elb Surg. 2014;23:227-35. 
8. Longo UG, Loppini M, Margiotti K, Salvatore G, Berton A, Khan WS, Maffulli $\mathrm{N}$, Denaro V. Unravelling the genetic susceptibility to develop ligament and tendon injuries. Curr Stem Cell Res Ther. 2015;10:56-63.

9. Mokone GG, Schwellnus MP, Noakes TD, Collins M. The COL5A1 gene and Achilles tendon pathology. Scand J Med Sci Sports. 2006;16:19-26.

10. Altinisik J, Meric G, Erduran M, Ates O, Ulusal AE, Akseki D. The BstUl and Dpnll variants of the COL5A1 gene are associated with tennis elbow. Am J Sports Med. 2015;43:1784-9.

11. García-Closas M, Lubin JH. Power and sample size calculations in casecontrol studies of gene-environment interactions: comments on different approaches. Am J Epidemiol. 1999;149:689-92.

12. Baumert P, Consortium GR, Stewart CE, Lake MJ, Drust B, Erskine RM. Variations of collagen-encoding genes are associated with exercise-induced muscle damage. Physiol Genomics. 2018:50:691-3.

13. Abrahams S, Posthumus M, Collins M. A polymorphism in a functional region of the COL5A1 gene: association with ultraendurance-running performance and joint range of motion. Int J Sports Physiol Perform. 2014;9:583-90.

14. O'Connell K, Knight H, Ficek K, Leonska-Duniec A, Maciejewska-Karlowska A, Sawczuk M, Stepien-Slodkowska M, O'Cuinneagain D, van der Merwe W. Posthumus $\mathrm{M}$, et al. Interactions between collagen gene variants and risk of anterior cruciate ligament rupture. Eur J Sport Sci. 2015;15:341-50.

15. Maffulli N, Margiotti K, Longo UG, Loppini M, Fazio VM, Denaro V. The genetics of sports injuries and athletic performance. Muscles Ligaments Tendons J. 2013:3:173-89.

16. Longo UG, Rizzello G, Berton A, Maltese L, Fumo C, Khan WS, Denaro V. Biological strategies to enhance rotator cuff healing. Curr Stem Cell Res Ther. 2013;8:464-70.

17. Maffulli N, Longo UG, Berton A, Loppini M, Denaro V. Biological factors in the pathogenesis of rotator cuff tears. Sports Med Arthrosc. 2011;19:194-201.

18. Stofkova A. Leptin and adiponectin: from energy and metabolic dysbalance to inflammation and autoimmunity. Endocr Regul. 2009:43:157-68.

19. Longo UG, Petrillo S, Berton A, Spiezia F, Loppini M, Maffulli N, Denaro V. Role of serum fibrinogen levels in patients with rotator cuff tears. Int J Endocrinol. 2014;2014:685820

20. Reddy GK. Cross-linking in collagen by nonenzymatic glycation increases the matrix stiffness in rabbit achilles tendon. Exp Diabesity Res. 2004;5:143-53.

21. Reddy GK. Glucose-mediated in vitro glycation modulates biomechanical integrity of the soft tissues but not hard tissues. J Orthop Res. 2003;21:738-43.

22. Longo UG, Franceschi F, Ruzzini L, Spiezia F, Maffulli N, Denaro V. Higher fasting plasma glucose levels within the normoglycaemic range and rotator cuff tears. Br J Sports Med. 2009:43:284-7.

23. Longo UG, Franceschi F, Ruzzini L, Rabitti C, Morini S, Maffulli N, Denaro V. Histopathology of the supraspinatus tendon in rotator cuff tears. Am J Sports Med. 2008:36:533-8.

24. Longo UG, Berton A, Khan WS, Maffulli N, Denaro V. Histopathology of rotator cuff tears. Sports Med Arthrosc. 2011;19:227-36.

25. Longo UG, Franceschi F, Ruzzini L, Rabitti C, Morini S, Maffulli N, Denaro V. Characteristics at haematoxylin and eosin staining of ruptures of the long head of the biceps tendon. Br J Sports Med. 2009;43:603-7.

26. Longo UG, Franceschi F, Spiezia F, Forriol F, Maffulli N, Denaro V. Triglycerides and total serum cholesterol in rotator cuff tears: do they matter? Br J Sports Med. 2010;44:948-51.

27. Teerlink CC, Cannon-Albright LA, Tashjian RZ. Significant association of fullthickness rotator cuff tears and estrogen-related receptor- $\beta$ (ESRRB). J Shoulder Elb Surg. 2015;24:e31-5.

28. Tashjian RZ, Granger EK, Farnham JM, Cannon-Albright LA, Teerlink CC. Genome-wide association study for rotator cuff tears identifies two significant single-nucleotide polymorphisms. J Shoulder Elb Surg. 2016;25:174-9.

29. Tashijian RZ, Granger EK, Zhang Y, Teerlink CC, Cannon-Albright LA. Identification of a genetic variant associated with rotator cuff repair healing. J Shoulder Elb Surg. 2016;25:865-72.

\section{Ready to submit your research? Choose BMC and benefit from:}

- fast, convenient online submission

- thorough peer review by experienced researchers in your field

- rapid publication on acceptance

- support for research data, including large and complex data types

- gold Open Access which fosters wider collaboration and increased citations

- maximum visibility for your research: over $100 \mathrm{M}$ website views per year

At $\mathrm{BMC}$, research is always in progress.

Learn more biomedcentral.com/submissions 